\title{
TRAINING IN MAKING ANIMATED SHORT FILMS AS AN EFFORT TO PROVIDE SOFT SKILLS IN THE ICT FIELD TO STUDENTS OF MEDIA KASIH ORPHANAGE FOUNDATION
}

\author{
Nurwati Nurwati $^{1 *}$, Yudi Santoso ${ }^{1}$, Ratna Kusumawardani ${ }^{1}$ \\ ${ }^{1}$ Budi Luhur University \\ *nurwati@budiluhur.ac.id
}

\begin{abstract}
The use of animation media is one of the many problems in learning in schools. Over time, the existence of supporting media for learning by using various basic media based on information technology such as short films with short duration of time is actually one of the alternatives to handle the saturation of the unpleasant conditions of students in teaching and learning activities. However, the use of animated film media is only used to present students' work. The use of Microsoft Power Point as a medium to create animated short films applies a scientific approach in which applying a scientific attitude and good knowledge is not enough if it is not supported by activities involving pycnomorphic or skills. This is so that training participants can experience positive development both in terms of knowledge and skills and it is hoped that scientific attitudes will arise to solve problems so that they are ready to face the times in their golden age.
\end{abstract}

Keywords: media animation, Microsoft power point, soft skills

\section{INTRODUCTION}

This Community Service activity is one of the goals is to fulfill the obligations of the Higher Education Tridarma by providing increased ability to use computer applications, namely Microsoft Power Point to children of the Media Kasih Orphanage Foundation. The purpose of the implementation of ICT (Information and Communication Technology) capacity building is to provide enthusiasm and motivation to the orphanage children and transmit ICT material through training in making animated short films using Microsoft Power Point.The partners in this Community service activity are the Media Kasih Orphanage Foundation located on Jalan Mutiara no. 12 RT 01/04 Kelurahan Cipadu, Kecamatan Larangan, Kota Tangerang, Banten 15155.This community service activity is related to the contribution of knowledge that is owned by the dedication team (lecturers and students) to provide enlightenment to the community, especially for the children of the Media Kasih Orphanage Foundation who are elementary school students up to senior high school. Material giving is made as comfortable as possible with the active pattern of students so that it is expected that training students are more active and inspired to learn ICT.

According to (Anon 2010) in language, "orphan" comes from Arabic. From fi'ilmadli "yatama" mudlori "'yaitamu" and mashdar "yatmu" which means: sad. Or say: alone. As for Syara terms, what is meant by orphans is a child whose father died before he was hospitalized. The limit of a child called orphan is when the child has been baligh and mature. While the orphan is not derived from Arabic, this word in Indonesian is attributed to a child whose mother has died, and an orphan is a child whose parents have died.Orphan Institute is a community organization engaged in orphanage development. Has the following roles: (a) fostering and educating orphans, (b) fostering faith, piety, and noble morality, according to (UPI 2011). The orphanage according to (UPI 2011) is a place to accommodate orphaned children. In orphanages, orphans (or the children their parents leave because they are not able) usually live, get education, and are also equipped with various skills to be useful in their lives later.

This Community Service activity as a learning process prepares the children of the Kasih Media Orphanage Foundation to be able to take opportunities and benefit themselves and their environment. The learning process is expected in accordance with Government Regulation No.19 on SNP in 2005, namely the learning process in the education unit is held interactively, inspiring, fun, challenging, 
motivates students to actively participate, and provides sufficient space for initiative, creativity, and independence in accordance with talents, interests, and physical and psychological development of students. This indicates that the teacher as the perpetrator of the learning process in the classroom, must be able to plan a learning strategy, so that the learning carried out can succeed well according to the goals of education according to (Indonesia 2002).

To facilitate training in making animated short films with Microsoft Power Point, the Community Service Team uses instructional media in the form of animated media with the aim of facilitating trainees in receiving and making this animated short film. As for according to (Siswanah 2013) learning media can change something abstract into concrete and complex ones become simple. The use of learning media will greatly assist the teaching and learning process so that quality learning is created. Learning media that has developed so rapidly is animation media. The use of learning media will greatly assist the teaching and learning process so that quality learning is created. Learning media that has developed so rapidly is animation media. The use of animation media is expected to generate motivation and stimulation of student learning activities, help the effectiveness of the learning process, attract and direct the attention of students in training to concentrate on the contents of the training, facilitate the achievement of goals to understand and remember the information provided, learning becomes more interesting, brings freshness and variety new to the teaching and learning experience so that training students are not bored and not passive.

Scientific learning according to (Khairul Akbar 2013) is learning that adopts the steps of scientists in building knowledge through scientific methods. The learning model that is needed is that which enables the cultivation of scientific thinking, the development of "sense of inquiry" and students' creative thinking skills according to Alfred De Vito, 1989 in (Khairul Akbar 2013). The learning model that is needed is able to produce the ability to learn according to Joice\& Weil, 1996 in (Khairul Akbar 2013), not only obtained a number of knowledge, skills, and attitudes, but more important is how the knowledge, skills and attitudes obtained by participants according to educated Zamroni, 2000 \&Semiawan, 1998 in (Khairul Akbar 2013). Scientific learning does not only view learning outcomes as the final estuary, but the learning process is considered very important. Therefore scientific learning emphasizes on process skills. The learning model based on improving science process skills is a learning model that integrates science process skills into an integrated material presentation system according to Beyer, 1991 in (Khairul Akbar 2013).The 1 earning model based on improving science process skills is a learning model that integrates science process skills into an integrated material presentation system according to Beyer, 1991 in (Khairul Akbar 2013). This model emphasizes the process of seeking knowledge rather than knowledge transfer, students are seen as learning subjects that need to be actively involved in the learning process, the teacher is only a facilitator who guides and coordinates learning activities. In this model students are invited to carry out the process of seeking knowledge regarding subject matter through various scientific process activities as carried out by scientists (scientist) in conducting scientific investigations according to Nur, 1998 in (Khairul Akbar 2013), thus students are directed to find itself various facts, constructing concepts, and new values needed for his life. The focus of the learning process is directed at developing students' skills in processing knowledge, finding, and developing their own facts, concepts, and values needed by Semiawan, 1992 in (Khairul Akbar 2013).

Scientific or scientific approach is a way or mechanism of learning to facilitate students to gain knowledge or skills with procedures based on a scientific method taken from the Ministry of Education and Culture, 2013 on (Khairul Akbar 2013). According to (Permana 2004) Microsoft PowerPoint is the most popular and most widely used presentation application program today. Using Microsoft PowerPoint you can design and make professional presentations easily and quickly and if necessary you can place presentations on the Web server so that all Internet users can read them. The latest version of Microsoft PowerPoint is Microsoft Office PowerPoint 2003. Microsoft Office Power Point 2003, hereinafter referred to as PowerPoint 2003, is a development of earlier versions of Microsoft PowerPoint that are concentrated so that the presentation application program is more user-friendly, more flexible, easier to integrate with other Microsoft Office 2003 application programs, you can work together on a network system better and can utilize the facilities available on the Internet and Intranet in a more optimal manner. 


\section{Partner Problem Formulation}

Based on the results of observations and direct discussions with partners, several problems were encountered, as follows:

a. How do you provide soft skills to students of Media Kasih Orphanage Foundation?

b. How to introduce Microsoft Power Point applications to students of the Media Kasih Orphanage Foundation?

c. How can students of the Media Kasih Foundation Foundation be able to create animated short films using Microsoft Power Point?

\section{Activity Objectives}

The objectives to be achieved in this training activity are:

a. Introducing the training participants the importance of mastering information technology and mastery skills of Microsoft Power Point applications.

b. Share knowledge and experience regarding facilities in Microsoft Power Point and the conveniences offered by this application.

c. Providing enthusiasm and motivation for orphaned children in living their lives by opening a perspective or way of thinking about the effectiveness of activities.

\section{Output Targets}

Output targets for this service are to introduce Microsoft Power Point applications to students of Media Kasih Orphanage Foundation and to guide these students to be able to create animated short films using Microsoft Power Point. With community service activities, it is expected that the students of Media Kasih Orphanage Foundation will have soft skills and new experience in the field of Information and Communication Technology (ICT), which in the end these students will be able to compete in the world of work with the soft skills they have.

\section{Method Of Application Of Ipteks}

The method of implementation is as follows:

1. This community service activity is preceded by prior observation to the place of service implementation.

2. Method of Lecture and discussion

This training activity was conducted by lecturing and discussion for 1 (one) day by gathering the trainees in one room. The provision of theories regarding training in making animated short films using Microsoft Power Point is done by direct practice in a computer laboratory with the hope that the trainees will easily and quickly understand the material presented by the service team.

3. Demonstration and mentoring methods

Demonstration and training activities are a follow-up activity carried out by the implementation team of dedication activities to lecture activities and discussions that have been conducted. This activity was carried out by demonstrating making animated short films using Microsoft Power Point. After that the training participants practiced the theories and demonstrations that were shown directly by being accompanied by the implementing team of community service activities. Mentoring is done with an individual and classical approach. The classical approach was carried out when giving theories about Microsoft Power Point and an individual approach was taken when the trainees made short animated films using Microsoft Power Point and the exercises provided to optimize the ability of the trainees.

\section{RESULT AND DISCUSSION}

Community Service Activities that have been carried out at the Media Kasih Orphanage Foundation on Training on Making Animated Short Films as an Effort to Provide Soft Skill in the ICT Field to Students of the Kasih Media Foundation Orphanage have received positive responses from trainees. It turned out that the training participants were familiar or used to use Microsoft PowerPoint. It was proven that the training participants were able to follow the training material and quickly absorb the material. It was illustrated by the excitement from the trainees' faces when they arrived at the final stages of the training, namely animated short films using Microsoft PowerPoint. The animated short 
film contains objects that move like people moving as if entering a bus and a bus that moves on the next slide that takes passengers, namely school students at the destination school. The training participants applauded and cheerfully got the results of the training moving as exemplified by the training instructor. Background display and image objects used have been prepared in the training folder.



Figure 1. First slide show

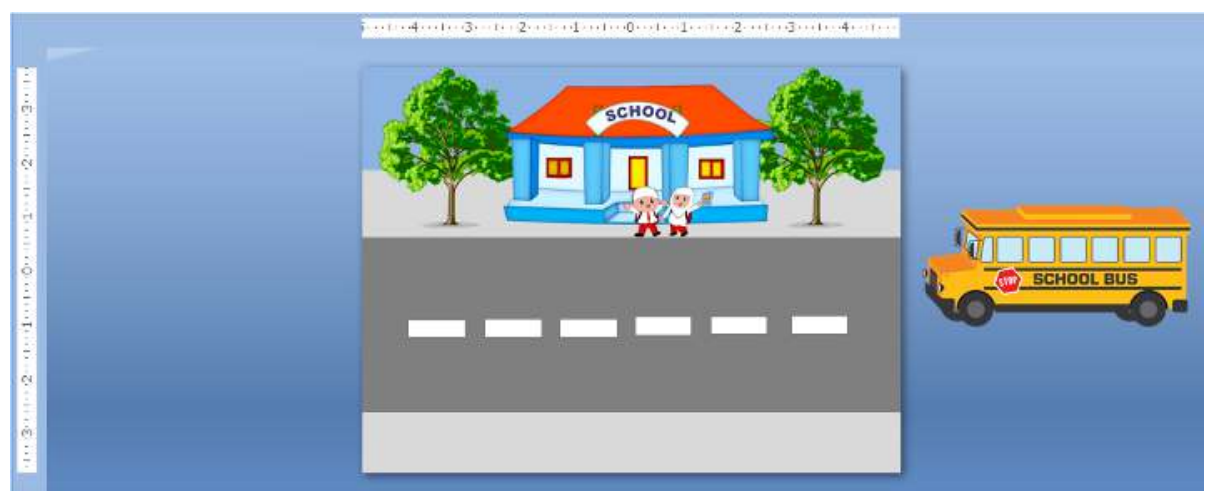

Figure 2. Second slide

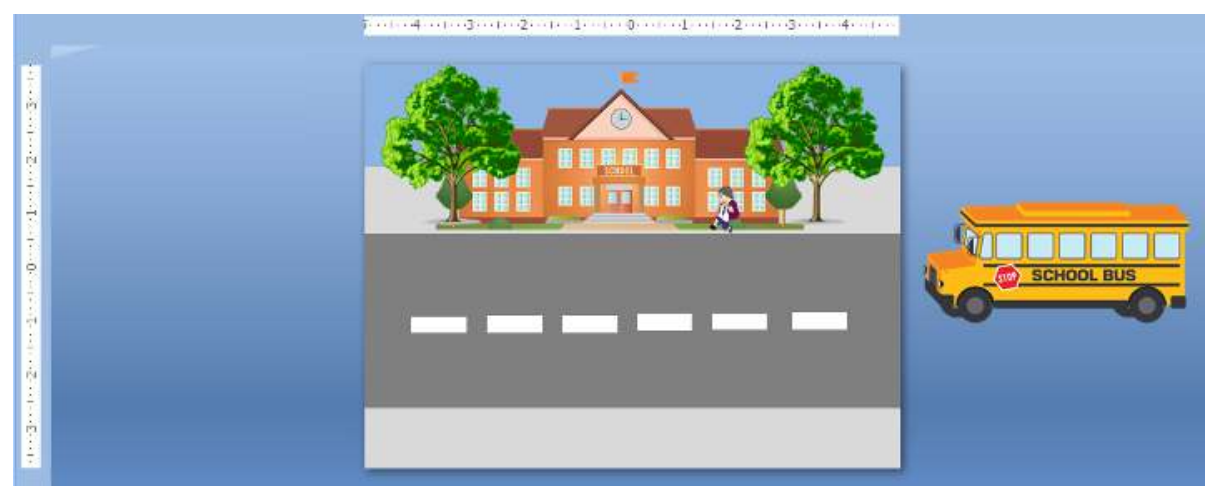

Figure 3. Third slide 


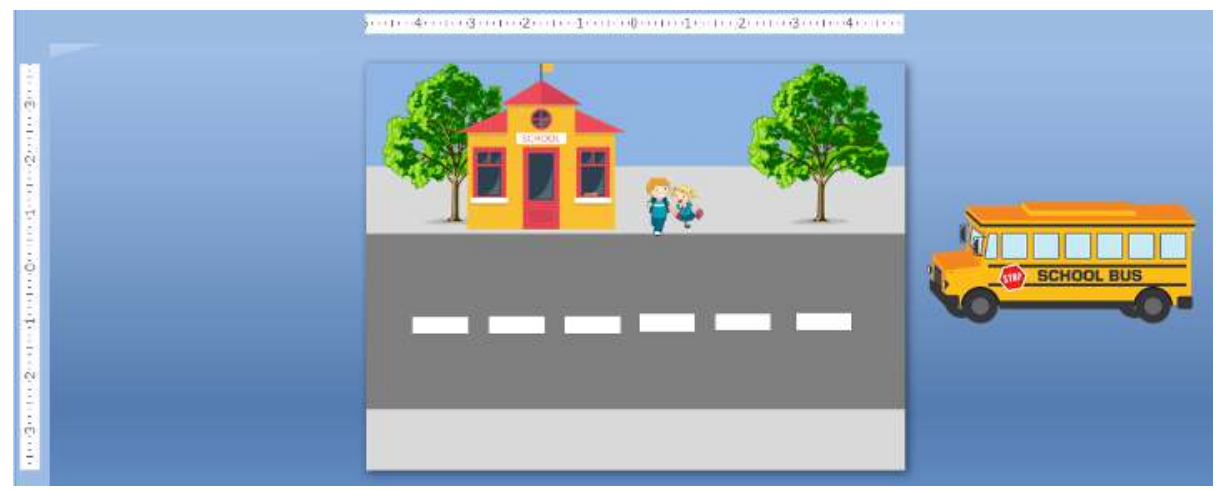

Figure 4. Fourth slide

After the four slides are done, the next step is to run the slides. The steps click on the Animations menu, select and click Custom Animation, click the add effect button, then click Entrance-random bars then click the play button.

\section{CONCLUSION}

Based on Community Service Activities entitled Training on Making Animated Short Films as Efforts to Debt Soft Skills in the ICT Field to Students of Media Kasih Orphanage, it can be concluded that knowledge of information technology has become a necessity that must be met by someone. This is because most of the work involves information technology assistance. In addition, the use of information technology is one of the main capital to deal with globalization and the advancement of information technology today. This training on making animated short films with Microsoft Power Point is expected to be able to make orphans open their insights (ways of thinking) and be able to organize their activities so that they become more effective and useful. Without giving up their childhood, all the skills they receive can still be accomplished. Based on the training material provided, this activity has benefited many parties. For trainees to add knowledge and experience using information technology. For students to add knowledge and experience interacting outside the campus environment and practice the knowledge gained on campus. For organizers as an effective promotional tool.

\section{REFERENCES}

Anon, (2010). Pengertian Anak Yatim Dan Kedudukannya Dalam Islam. Available at: https://alikhlaskebonduren.wordpress.com/2010/01/13/pengertian-anak-yatim-dankedudukannya-dalam-islam/.

Imanto, T. (2007). Film Sebagai Proses Kreatif Dalam Bahasa Gambar. Jurnal Komunikologi Vol, 4(1).

Indonesia, P.R., 2002. Undang-Undang Republik Indonesia Nomar 19 Thun 2002 Tentang Hak Cipta. , (1), pp.1-36. Available at: http://dri.ipb.ac.id/PDF_file/UU_19_2002_Hak Cipta.pdf.

Jubilee Enterprise, elex media komputindo, (2010). Kupas Tuntas PowerPoint 2010. In Jakarta, pp. 110 . Available at: https://books.google.co.id/books?id=YxJpDrjoOEEC\&printsec $=$ frontcover\&hl $=\mathrm{id} \# \mathrm{v}=$ onepage $\&$ $\mathrm{q} \& \mathrm{f}=$ false.

Khairul Akbar, S., (2013). Kurikulum 2013 Dengan Pendekatan Scientific Dalam Pembelajaran Matematika. Available at: https://www.kompasiana.com/www.khairulakbar.com/kurikulum- 
2013-dengan-pendekatan-scientific-dalam-pembelajaranmatematika_55febcfbee9273860a9280ee.

Permana, B., (2004). Microsoft Power Point 2003, Available at: https://books.google.co.id/books?id=mmvQufFZmT0C\&pg=PA1\&dq=microsoft + powerpoint $+\mathrm{a}$ dalah\&hl=id\&sa $=$ X\&ved $=0$ ahUKEwjD46KXxo3XAhXLvY8KHY-

YDekQ6AEIJTAA\# $\mathrm{v}=$ onepage $\& \mathrm{q}=$ microsoft powerpoint adalah\& $\mathrm{f}=$ false.

Siswanah, E., 2013. Penggunaan Media Animasi Dalam Pembelajaran Trigonometri Untuk Meningkatkan Hasil Belajar Mahasiswa Tadris Matematika IAIN Walisongo Semarang. Available at: http://download.portalgaruda.org/article.php?article=396154\&val=8654\&title=PENGGUNAAN MEDIA ANIMASI DALAM PEMBELAJARAN TRIGONOMETRI UNTUK MENINGKATKAN HASIL BELAJAR MAHASISWA TADRIS MATEMATIKA IAIN WALISONGO SEMARANG.

UPI, 2011. Anak Yatim Piatu. Available http://file.upi.edu/Direktori/FIP/JUR. PEND._LUAR_BIASA/195604121983011-

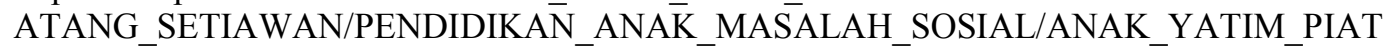
U.pdf.

Yunita Syahfitri, 2011. Teknik Film Animasi Dalam Dunia Komputer. Jurnal Saintikom, Vol. 10 /. Available at: https://lppm.trigunadharma.ac.id/public/fileJurnal/hpqo5-Jurnal-YUN-animasi.pdf. 